\title{
On Vācaspatimišra's Explanation of the Cause of samyoga
}

\section{Koki ARUGA}

Vyāsa refers to eight kinds of interpretation of adarśana in his Yogabhāṣya (YB). ${ }^{1)}$ They are worth examining from the viewpoint of Sāṃkhya studies. I shall focus on two of them and discuss the cause of samyoga in Sāmkhya and Yoga texts with special reference to Vācaspatimiśra's explanation of adarśana in his Tattvavaiśăradī (TV). The two are as follows: 1) gunānām adhikārah 2) arthavattā guñānām.

The Yogasütra(YS) says that avidy $\bar{a}$ is the cause of samyoga. ${ }^{2}$ Samyoga is, on the one hand, described as the cause of unfavorable things (duhkha). ${ }^{3)}$ However, on the other hand, YS 2.23 tells us that samyoga which is caused by avidy $\bar{a}$ brings the perception of capabilities (śaktis) of purușa and prakrti. This perception seems favorable to humans. Vyāsa interprets the perception of objects and of the Seer as bhoga (experience) and apavarga (liberation) respectively. ${ }^{4)}$ But he carefully tells us, in commenting on YS 2.23, that samyoga is not the cause of mokșa. He explains that darsana, which is the opposite of adarśana, is the cause of separation between purușa and prakrti, and he asserts adarśana to be the cause of samyoga. His comment makes it clear that adarśana is, in his mind, functionally equivalent to avidya

Nevertheless, when we consider this idea, we cannot but feel unsettled in the explanation of the relation of purușa and prakrti in the Sāmkhyakārika (SK), for we cannot find that either adarśana or avidy $\bar{a}$ play any important role in it. ${ }^{5)}$ When he explains the cause of samyoga, Íśvarakṛṣna only states: puruṣaya darśanārtham kaivalyārtham tathā pradhānasya. ${ }^{6)}$ The commentators primarily follow the view that samyoga is for the sake of puruṣa's seeing primordial matter as well as his absolute isolation. What is to be noticed is that their commentaries introduce the idea of upacāra (metaphor) in explaining 
the relation of purusa and prakrti. ${ }^{7)}$ In this idea, the conjunction (samyoga) of purusa and prakrti is a metaphorical expression and there is no real 'conjunction' of the two.

The author of the Yuktidipikā(YD) trys to make the idea of upacāra understandable. He declares that the relation of purusa and prakrti is proximity (sannidhi). ${ }^{8}$ According to him, samyoga is possible where any samyogas enumerated by his opponent do not exist. ${ }^{9)}$ He states as follows: anyas tu śāstrìyah samyogo' rthanimittah (While another 'samyoga' which is scriptural is that which is occasioned by purpose). ${ }^{10}$. The adjective 'śastriya' in his statement cannot be overlooked. Although it is clearly meant that the samyoga in the kārikā is 'śâstriya' and is understood as 'arthanimitta', it is not clear whether 'śāstrìya' is used so as to refer directly to İ́varakṛ̦ṇa's kārikā or rather merely to imply a certain authoritative source.

Explanatory descriptions of the real relation between purusa and prakrti are often given using the concept of yogyata ${ }^{11)}$ However, there may arise the problem: if yogyatā belonged to puruṣa, could puruṣa really be liberated? Or can puruṣa intrinsically be isolated, as SK says? Even if samyoga is yogyatā, the result is the same. In fact, we find the view that samyoga is yogyata in the Tattvakaumudī. It is offered as the objection by Vācaspatimiśra to introduce SK66 $6^{12)}$, which only says that no further creation takes place in spite of samyoga because there is no motive for it. In addition, the author of YD refers to samyoga which is characterized by yogyat $\bar{a}$ as one of the samyogas enumerated by the opponent. ${ }^{13)}$ Therefore, it should be noted that yogyat $\bar{a}$ cannot be samyoga in itself. Thus, the samyoga which is construed as yogyata is not necessarily favorable to the Sāmkhya philosophy. The contexts in which yogyat $\bar{a}$ is employed are considered to require the conditions of metaphorical expression. ${ }^{14)}$

Furthermore, YD refers to certain ācāryas' view of bondage. According to this, the ācāryas call samyoga 'adhikārabandha'. ${ }^{15)} \mathrm{P}$. Chakravarti pointed out that adhikārabandha was refuted by Kumārila in his Ślokavārttika. ${ }^{16)}$ Neither of these texts give us enough information about who the ācāryas are. However, it can be said that adhikāra, in the view of some Sāmkhya teachers, 


\section{(34) On Văcaspatimiśra's Explanation of the Cause of samyoga (K. ARUGA)}

is of great importance in explaining the relation between puruṣa and pradhāna.

It is possible to ask if the adhikära and the arthavattva of gunas in YB share the same sources with the references made by the author of the YD and Kumārila. However our materials are not sufficient to draw a conclusion. For instance, while 'adhikāra' is explained as 'yogyatva' in the slokavārttika, the author of YD does not refer to 'yogyatva (tā)' when he discusses the àcäryas' view of adhikarabandha. What we can say is that there still is the fact that adhikāra and arthavattva seem to be ideas held by Sāmkhya teachers.

Vācaspatimiśra describes Vyāsa's eight kinds of interpretation of the word 'adarśana' as Sāmkhya tenets in TV on YB 2.23. ${ }^{17)}$ However he does not refer to their sources. He mainly shows that these interpretations are derived from the negative prefix 'a-' in adarśana. It is well known that, according to one popular formation of the grammarians, the negative prefix 'a-' can give six different meanings. Which meaning it has is dependent upon what the negated compound denotes. And the functions of this negative prefix are called prasajyapratiședha and paryudāsa. Vācaspatimiśra, when he comments on adarśana in YB 2.23, introduces these terms. He means that six Sāmkhya tenets concerning the interpretation of the word 'adarsana' are explained by the two types of negation. But there is a difficulty in believing that the Sämkhya teachers regarded adarśana, the cause of samyoga, as to be interpreted in the meanings of prasajyapratisedha and paryudāsa because there is no evidence offered for this. It is not even certain that the other commentators consider all of the interpretations of the the word 'adarsana' to be those of Sāmkhya teachers. Vyāsa only states that these interpretations are mentioned in the śāstra ${ }^{18)}$ and the Yogaśāstravivarana explains that the śāstras are darśanāntaras. ${ }^{19)}$

In spite of the explanation in $\mathrm{TV}$, there is no evidence that the six kinds of interpretation of adarśana are connected with prasajapratiședha and pary$u d \bar{a} s a$ in other Sāmkhya and Yoga texts. They do not completely match the meanings which the negative prefix 'a-' gives. Therefore it is difficult to suppose that all six of them are originally based on the prefix 'a-' in adarśana. It is rather possible that Vācaspatimiśra only followed Vyāsa and gave the 
explanation.

Why did Vācaspatimiśra introduce prasajyapratiședha and paryudāsa? As we have seen above, arthavattā in Sāmphya is said to be of puruṣa, while in YB it is of gunas. There is a similarity in employing it to explain the cause of samyoga, but differentiation is required by the consideration of its locus. Vācaspatimiśra rejected the arthavatta in YB. ${ }^{20)}$ If he had intended to cover all of the Sāmkhya views on the cause of samyoga, he should have referred to 'artha' in SK. However the arthavatta in YB is of gunas only. By adopting prasajyapratiședha and paryudāsa in his comment on six of Vyāsa's eight kinds of interpretation of adarśana, he restricted his explanation of the cause of samyoga to the attributions of gunas. In this way he could leave the arthavattā of puruṣa uninjured.

1) The Yogasūtras of Patañjali with the Scholium of Vyāsa and the Commentary of Vācaspatimiśra, ed. by R.S. Bodas, Bombay Sanskrit and Prakrit Series XLVI, 1917, pp.93-95. In this paper I make use of this edition of the Yogasutra, the Yogabhāṣya and the Tattvavais̄āradī.

2) YS 2.24.

3) YS 2.17.

4) YB, p. 92.

5) Cf. P. Chakravarti, Origin and Development of the Sämkhya System of Thought, $1975^{2}$, p. 140.

6) SK 21.

7) For instance, see Taishō Shinsh̄̄ Daizōkyō No. 2137, Sāṃkhyavrtti and Sāmkhyasaptativrtti on SK 20.

8) R.C. Pandeya, Yuktidipikā, p. $89^{1-2}$. Here I use proximity for sannidhi. The author of YD grounds the usage of sannidhi on occupying the same spot which is figuratively expressed.

9) Similar enumerations of the samyogas are, as already pointed out, found in the Māthara, the Sāmkhyasaptativrtti and the Jayamaingalā. Cf. E.A. Solomon, The Commentaries of the Sāmkhya Kārikā-A Study, p. 50. Here we have to pay attention to the enumeration in the Vaiśeșika doctrine. Cf. Vaiśsșikasütra 7.2.10 (Here I follow the numbering in the text of G.O.S. 136.). In YD the opponent says: “vijñatam samyogadvayam." What 'samyogadvayam' indicates is not clear. However, if it indicates karmaja and samyogaja, it reminds us of the classification of samyoga in the Praśastapādabhāṣya.) 
(36) On Vācaspatimiśra's Explanation of the Cause of samyoga (K. ARUGA)

10) pp. 88-89.

11) Cf. M. Hulin, Sãmkhya Literature, A History of Indian Literature Vol. I, p. 147.

12) S.A. Srinivasan, Vācaspatimiśras Tattvakaumudī, Alt- und Neu-Indische Studien 12 , p. 172.

13) p. 88.

14) For instance, purușa and pradhäna are inevitably called bhoktr and bhogya respectively.

15) pp. 89-90.

16) P. Chakravarti, op. cit., p. 233.

17) pp.93-95. These can be presented as follows: a) adhikāra of the gunas b) non production of primary mind c) arthavattā of the gunas d) avidya (nescience) or the seed of mind e) the manifestation of samskāra for production $f$ ) the cognitive faculty g) the characteristic of puruṣa and pradhāna h) the knowledge (of sounds, touches and so on) which is comprehension.

-relative to gunas: h); a),c),d), e) and f) (These are explained in the meaning of paryudāsa.); b) (This is explained in the meaning of prasajyapratiședha.)

-relative to puruṣa and gunas: g)

Vācaspatimiśra mentions that only e) is accepted here because the diversity of experience of puruṣas cannot be explained in the rest.

18) p. 95.

19) Madras Government Oriental Series No. XCIV, p.200. Cf. T.S. Rukmani, Yogavārttika of Vijñānabhikșu, Vol, II, p. 163.

20) Cf. n. 17).

〈Key Words〉 adarśana, saṃyoga, Yogabhāṣya, Tattvavaiśāradī, Vācaspatimiśra (Graduate Student, University of Tokyo) 